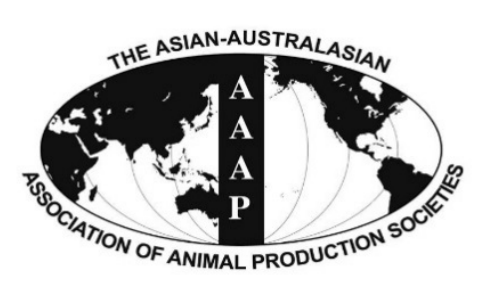

\title{
Ramie Leaf Extracts Suppresses Adipogenic Differentiation in 3T3-L1 Cells and Pig Preadipocytes
}

\author{
Joomin Lee, Ah-Ra Kim, and Jae-Joon Lee* \\ Department of Food and Nutrition, College of Natural Science, Chosun University, Gwangju 501-759, Korea
}

\begin{abstract}
The present study was carried out to evaluate the anti-obesity effect of different concentrations of extracts of hot airdried ramie leaf (HR) and freeze-dried ramie leaf (FR) in 3T3-L1 cells and pig preadipocytes. To analyze the effect on cell proliferation, cells were treated with $25 \mu \mathrm{g} / \mathrm{mL}$ or $100 \mu \mathrm{g} / \mathrm{mL}$ HR or FR extract for 2 days. Cell differentiation was evaluated by measuring glycerol-3phosphate dehydrogenase and lipoprotein lipase (LPL) activities and intracellular triglyceride content. Treatment with either HR or FR extracts inhibited the proliferation of 3T3-L1 cells and pig preadipocytes in a dose-dependent manner. HR extract treatment inhibited the differentiation of both cell types more effectively than FR treatment. The extent of triglyceride accumulation decreased significantly in both cells following either HR or FR treatment. Furthermore, LPL activity significantly decreased after treatment with HR or FR extract. These results indicated that HR and FR extracts may inhibit proliferation and differentiation of 3T3-L1 cells and pig preadipocytes. Further studies are needed to explore the anti-obesity effect of HR and FR extracts. (Key Words: Ramie Leaf, Preadipocytes, Proliferation, Differentiation, Obesity)
\end{abstract}

\section{INTRODUCTION}

Obesity is considered a public health problem and is caused when energy intake exceeds energy expenditure. Obesity is closely linked to metabolic diseases such as diabetes, hypertension, heart disease, and cancer (Cao, 2007). Adipogenesis is a sequence of events that includes adipose tissue proliferation and differentiation, and lipid accumulation (Fernyhough et al., 2007). Obesity causes normal or excessive fat accumulation and adipocyte differentiation (González-Castejón et al., 2011). Many studies have shown that plant-derived foods have the potential to reduce obesity (Boeing et al., 2012). Furthermore, understanding the anti-obesity mechanism of plant-derived products will help prevent obesity. In vitro and in vivo evidence suggests that natural compounds inhibit obesity by inhibiting adipocyte differentiation and altering lipid metabolism (Yun, 2010).

\footnotetext{
* Corresponding Author: Jae-Joon Lee. Tel: +82-62-230-7725, Fax: +82-62-234-7452, E-mail: leejj80@chosun.ac.kr Submitted May 1, 2015; Revised Jul. 7, 2015; Accepted Dec. 15, 2015
}

Ramie (Boehmeria nivea L.) belongs to the family Urticales and is widely cultivated in Asian countries such as Korea, India, and China. Ramie is used as a traditional herbal medicine and has been shown to have antioxidant, anti-hepatitis B virus, anti-inflammatory, and antifungal effects (Lee et al., 2009; Xu et al., 2011; Wei et al., 2014). Ramie is a rich source of amino acids, vitamins, minerals, dietary fibers, and flavonoids (Lee et al., 2009). Recent studies have shown that the physiochemical composition and the antioxidant properties of ramie vary between hotair-dried ramie leaf (HR) and freeze-dried ramie leaf (FR) (Kim et al., 2014a, b). However, the effect of preparation method on its anti-adipogenic effect has not yet been evaluated. In the present study, we used 3T3-L1 cells, clonal line of preadipocyte that was capable of differentiating adipocyte and porcine preadipocytes (Green and Kehinde, 1975). Pig has been used as an ideal model due to its similar metabolic features, cardiovascular systems, and organ sizes with humans (Houpt et al., 1979; Spurlock and Gabler, 2008; Litten-Brown et al., 2010). It may be very helpful to understand the effect of HR and FR extracts on adipogenesis using these model. 


\section{MATERIALS AND METHODS}

\section{Preparation of ramie leaf extract}

Ramie leaf was purchased at a local market in Gwangju, Korea. It was rinsed in water and blanched in boiling water for 1 minute. Afterwards, the blanched portion was drained of water. HR was prepared by placing in a $60^{\circ} \mathrm{C}$ hot-air oven for $40 \mathrm{~h}$. FR was dehydrated at $-70^{\circ} \mathrm{C}$ for $72 \mathrm{~h}$. HR and FR powders were added with $80 \%$ ethanol solution. Using a heating mantle, solutions were heated at $65^{\circ} \mathrm{C}$ for 9 $\mathrm{h}$ with constant stirring and then filtered through filter paper. Samples were concentrated on a rotary evaporator and stored at $-70^{\circ} \mathrm{C}$, before analysis.

\section{T3-L1 cell culture conditions}

3T3-L1 murine preadipocytes were obtained from American Type Culture Collection (Manassas, VA, USA) and cultured as described previously (Chen et al., 1997). For the proliferation experiments, cells $\left(1 \times 10^{5}\right)$ were plated in 6-well plates and media were changed every 2 days. To induce cell differentiation, cells $\left(3 \times 10^{4}\right)$ were plated in 6well plates and were grown to confluence in Dulbecco's modified Eagle's medium (DMEM) supplemented with $10 \%(\mathrm{v} / \mathrm{v})$ fetal bovine serum (FBS). Media was changed every 2 days until 14 days. On day 1, confluent cells were changed to differentiation medium, which consisted of 10 $\mu \mathrm{g} / \mathrm{mL}$ insulin, $1 \mu \mathrm{M}$ dexamethasone and $0.5 \mu \mathrm{M}$ 3-isobutyl1-methylxanthine (IBMX) in DMEM supplemented with $10 \%$ FBS. From day 2, media was replaced with $10 \mu \mathrm{g} / \mathrm{mL}$ insulin in DMEM supplemented with 10\% FBS. Stock solutions of Ramie leaf were prepared in dimethyl sulfoxide (DMSO) and diluted with medium prior to experimental procedures.

\section{Pig preadipocyte isolation}

Pig preadipocytes were obtained from newborn male pigs. The back fat tissue taken from the pigs were treated with collagenase treatment. The isolated tissue was digested with collagenase for 40 minutes at $37^{\circ} \mathrm{C}$. After removal of undigested tissue using nylon mesh, tissue was centrifuged at $1,500 \times g, 10$ minutes. The cell pellet was placed into a Krebs-Ringer Bicarbonate buffer, centrifuged at $1,796 \times g$ for 10 mins, and cells were collected.

\section{Pig preadipocyte cell culture conditions}

Pig preadipocyte cells were cultured as described previously (Suryawan et al., 1997). For the proliferation experiments, cells $\left(5 \times 10^{5}\right)$ were plated in DMEM/F-12 supplemented with $10 \%(\mathrm{v} / \mathrm{v})$ FBS. Differentiation was initiated by the addition of insulin $(600 \mu \mathrm{g} / \mathrm{mL})$, transferrin $(1 \mu \mathrm{g} / \mathrm{mL})$, and hydrocortisone $(500 \mu \mathrm{g} / \mathrm{mL})$ in DMEM/F12 media with $10 \%$ FBS.

\section{Determination of cell viability}

Cells were treated with DMSO (control) or various concentrations of each Ramie leaf extract for 2 days. Cells were washed with phosphate-buffered saline (PBS) and cells were collected cells using trypsin. After centrifugation, cell proliferation was determined using a hemocytometer and the trypan blue exclusion assay.

\section{Measurement of cell differentiation}

Glycerol-3-phosphate dehydrogenase (GPDH) activity was measured according to the method of Wise and Green (1979). After removing the culture media, differentiated cells were washed with PBS and lysed in a pH 7.4 buffer consisting of $0.25 \mathrm{M}$ sucrose, $5 \mathrm{mM}$ Tris base, $1 \mathrm{mM}$ ethylenediaminetetraacetic acid, and $1 \mathrm{mM}$ dithiothreitol. After centrifugation, GPDH activity in the supernatant was measured.

\section{Quantification of triglyceride content}

Cellular triglyceride content was isolated from the supernatants of differentiated cells by homogenization. Supernatant $(5 \mu \mathrm{L})$ was mixed with free glycerol assay reagent $(160 \mu \mathrm{L})$ in a 96 -well plate. After incubation for 5 mins at $37^{\circ} \mathrm{C}$, the absorbance of the solution was measured at $540 \mathrm{~nm}$ using a microplate reader. The absorbance was measured again after adding triacylglycerol reagent $(40 \mu \mathrm{L})$.

\section{Measurement of lipoprotein lipase expression}

Lipoprotein lipase (LPL) activity was measured by detecting liberated $3 \mathrm{H}$ triolein substrate emulsion according to previously reported method (Nilsson-Ehle and Schotz, 1976). LPL activity was expressed as units of fatty acid released per gram of tissue.

\section{Statistical analysis}

All data are expressed are means \pm standard error. All results were compared by one-way analysis of variance using the statistical package of social science (SPSS) program. Group means were considered significantly different at $\mathrm{p}<0.05$.

\section{RESULTS}

\section{Ramie leaf extract inhibited the viability of 3T3-L1 cells and pig preadipocytes}

Initially we examined the effect of ramie leaf extracts on viability of 3T3-L1 cells and pig preadipocytes. As shown in Figure 1A, the viability of 3T3-L1 cells did not show any difference between HR and FR extract at $24 \mathrm{~h}$ (data not shown), but examined the significance of 100 $\mu \mathrm{g} / \mathrm{mL}$ HR or FR extract after $48 \mathrm{~h}$. Treating pig preadipocytes with $25 \mu \mathrm{g} / \mathrm{mL}$ or $100 \mu \mathrm{g} / \mathrm{mL}$ HR or FR 

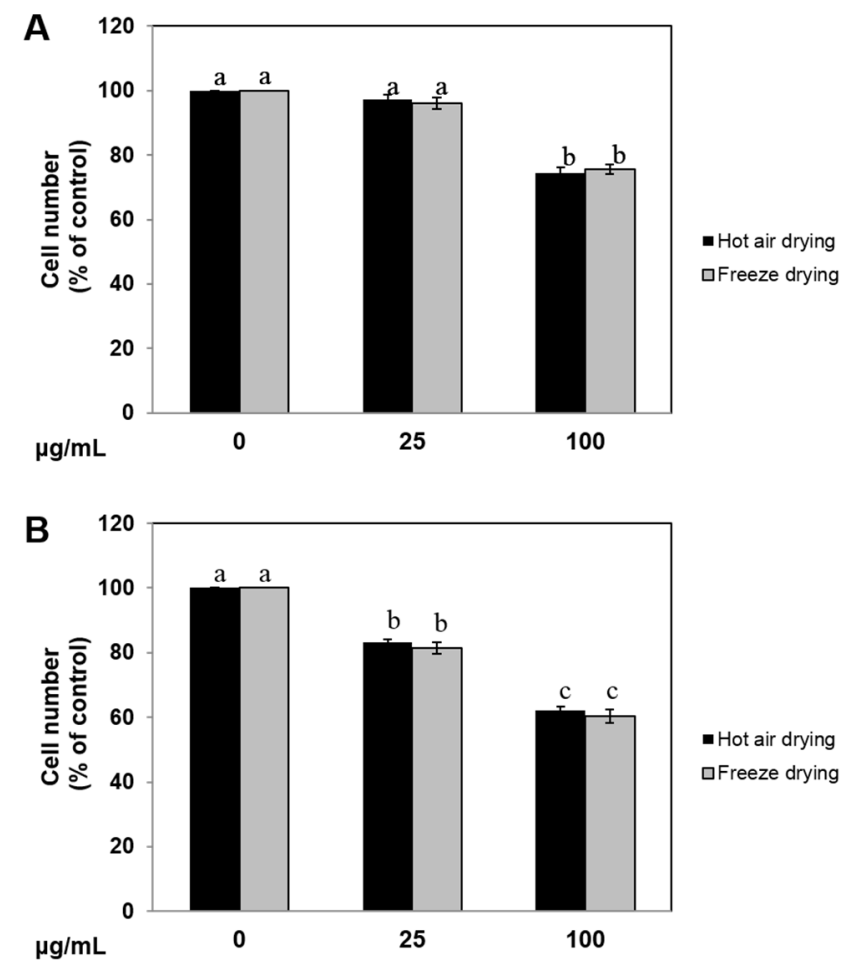

Figure 1. Effects of hot air-dried ramie leaf (HR) or freeze-dried ramie leaf (FR) extracts on viability of 3T3-L1 preadipocytes (A) and pig preadipocytes (B) after 2-day treatment. Cell viability was determined by counting cells with a hemocytometer. Reported values are means \pm standard error. ${ }^{a-c}$ Significantly different $(\mathrm{p}<0.05)$ compared with each control by one-way analysis of variance followed by Tukey's test. Each experiment was repeated at least triple.

extract significantly inhibited their viability after $48 \mathrm{~h}$ (Figure 1B). These results indicated that $\mathrm{HR}$ and FR extracts reduced the viability of pig preadipocytes at lower concentrations than that required for 3T3-L1 cells.

\section{Ramie leaf extract reduced differentiation of 3T3-L1 cells and pig preadipocytes}

We analyzed the effect of ramie leaf extract on the differentiation of 3T3-L1 cells and pig preadipocytes. Compared to DMSO treatment (control), the treatment of 3T3-L1 cells with $100 \mu \mathrm{g} / \mathrm{mL}$ HR or FR extract for $48 \mathrm{~h}$ resulted in 36\% and 34\% inhibition, respectively, of GPDH activity. The two drying methods did not affect 3T3-L1 cell differentiation following treatment for $48 \mathrm{~h}$ (Figure 2A). The HR extract inhibited the differentiation of pig preadipocytes at $100 \mu \mathrm{g} / \mathrm{mL}$. However, the FR extract suppressed the differentiation in a concentration-dependent manner (Figure 2B). These data indicate that the HR extract is superior to FR extract in inhibiting the differentiation of pig preadipocytes.

\section{Effect of ramie leaf extract on lipid accumulation in pig preadipocytes}

We measured the effect of ramie leaf extract on lipid accumulation in pig preadipocytes. Figure 3 shows the proliferation of pig preadipocytes after 2 days of cultivation.
After 4 days of cultivation, cells had reached confluency. At 6 days, compared to the control, HR and FR extract treatment at a concentration of $100 \mu \mathrm{g} / \mathrm{mL}$ inhibited lipid accumulation in pig preadipocytes. This finding indicates that HR and FR extract inhibited adipocyte differentiation.

\section{Ramie leaf extract inhibited triglyceride accumulation in 3T3-L1 cells and pig preadipocytes}

To explore the effect of ramie leaf extract on intracellular triglyceride accumulation, 3T3-L1 cells and pig preadipocytes were exposed to HR and FR extract for 6 days. HR and FR extract at a concentration of $25 \mu \mathrm{g} / \mathrm{mL}$ decreased triglyceride levels by $11.6 \%$ and $9.6 \%$, respectively. HR and FR extract at a concentration of $100 \mu \mathrm{g} / \mathrm{mL}$ reduced triglyceride levels by $29.9 \%$ and $26.6 \%$, respectively (Figure 4A). Triglyceride accumulation in pig preadipocytes was inhibited by $15 \%$ following treatment with $\mathrm{HR}$ extract at $25 \mu \mathrm{g} / \mathrm{mL} ; 100 \mu \mathrm{g} / \mathrm{mL}$ HR inhibited triglyceride accumulation by $44.5 \%$. FR extract also decreased triglyceride content in pig preadipocytes, but no significant changes were observed at $25 \mu \mathrm{g} / \mathrm{mL}$ (Figure 4B). These results demonstrate that both ramie leaf extracts inhibited the accumulation of triglycerides in 3T3-L1 and preadipocytes and that HR extract was more effective than FR extract in inhibiting triglyceride accumulation. 

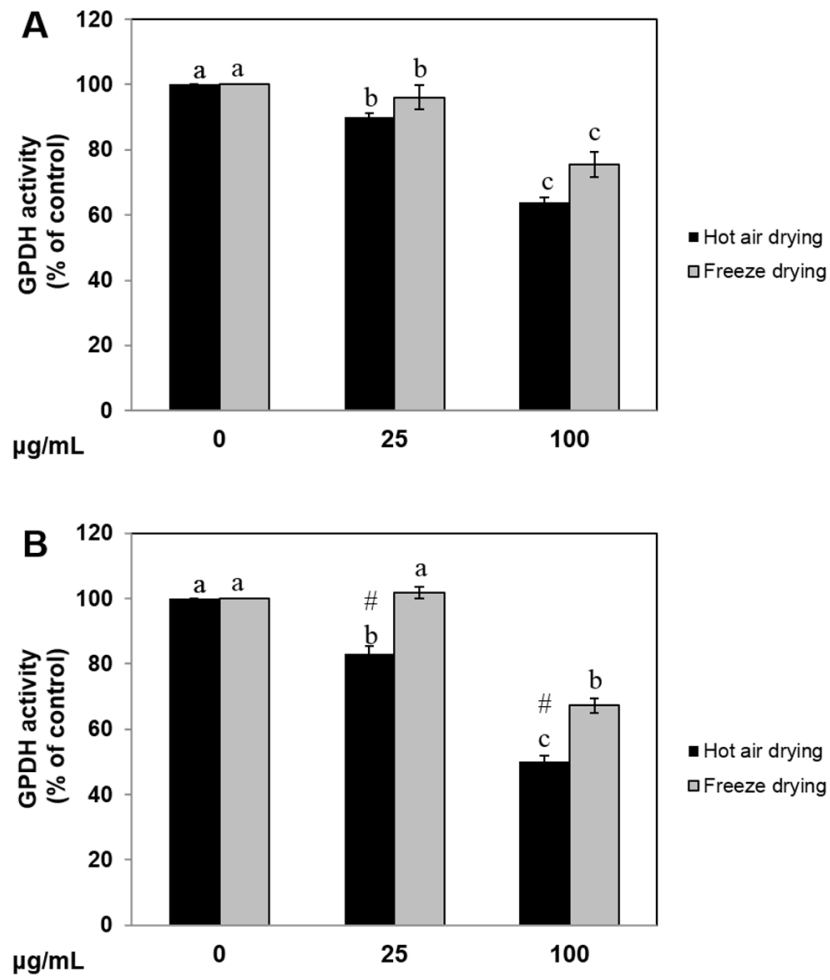

Figure 2. Effects of hot air-dried ramie leaf (HR) or freeze-dried ramie leaf (FR) extracts on differentiation of 3T3-L1 cells (A) and pig preadipocytes (B). Cell differentiation was determined by glycerol-3-phosphate dehydrogenase (GPDH) activity. Reported values are means \pm standard error. ${ }^{a-c}$ Values with different superscripts are significantly different at $\mathrm{p}<0.05$ according to Tukey's test. \# Significantly difference compared with freeze drying at $\mathrm{p}<0.05$ according to Student's $t$-test. Each experiment was repeated at least triple.

Ramie leaf extract inhibited lipoprotein lipase activity in 3T3-L1 cells and pig preadipocytes

Because LPL is a key factor in the development of obesity (Wang and Eckel, 2009), we evaluated the effect of HR and FR extracts on LPL activity in 3T3-L1 cells and pig preadipocytes. As shown in Figure 5A, compared to the control, treatment with $100 \mu \mathrm{g} / \mathrm{mL}$ HR or FR significantly inhibited LPL activity in 3T3-L1 cells. In pig preadipocytes, treatment with HR extract decreased LPL activity at both concentrations $25 \mu \mathrm{g} / \mathrm{mL}$ and $100 \mu \mathrm{g} / \mathrm{mL}$ (Figure 5B). HR

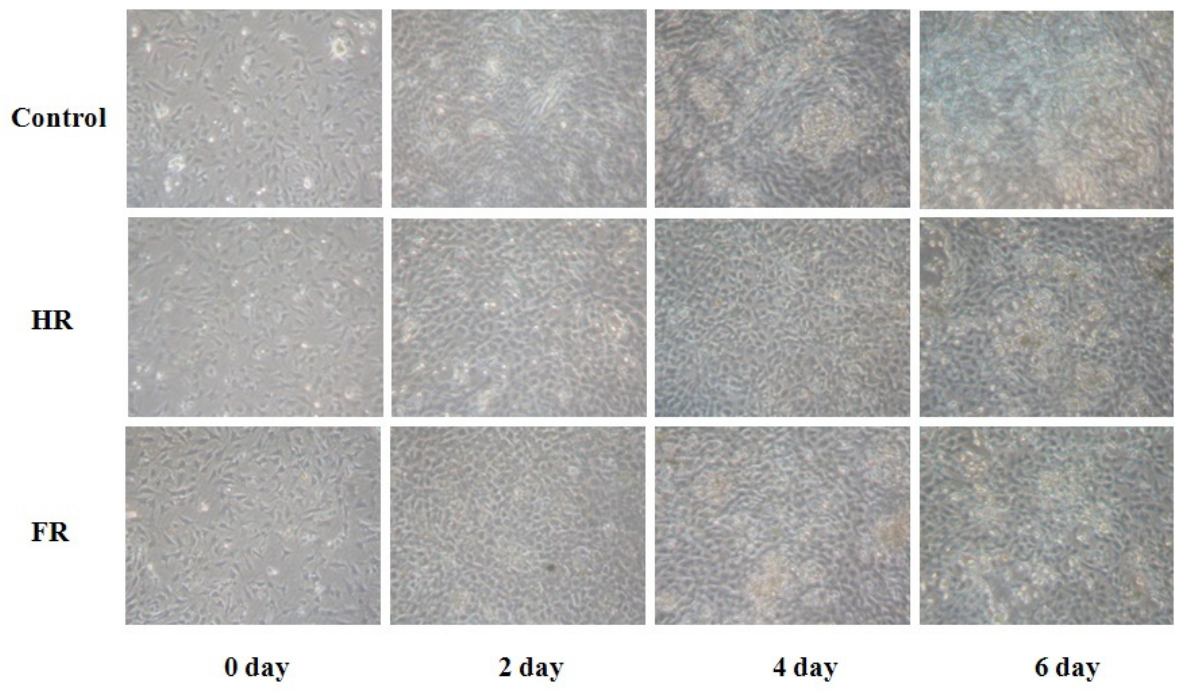

Figure 3. Micrographs showing differentiation of pig preadipocytes treated with air-dried ramie leaf (HR) or freeze-dried ramie leaf (FR) extracts. Pig preadipocytes treated with HR or FR extracts $(100 \mu \mathrm{g} / \mathrm{mL})$ were incubated for 6 days. Each experiment was repeated at least triple. 

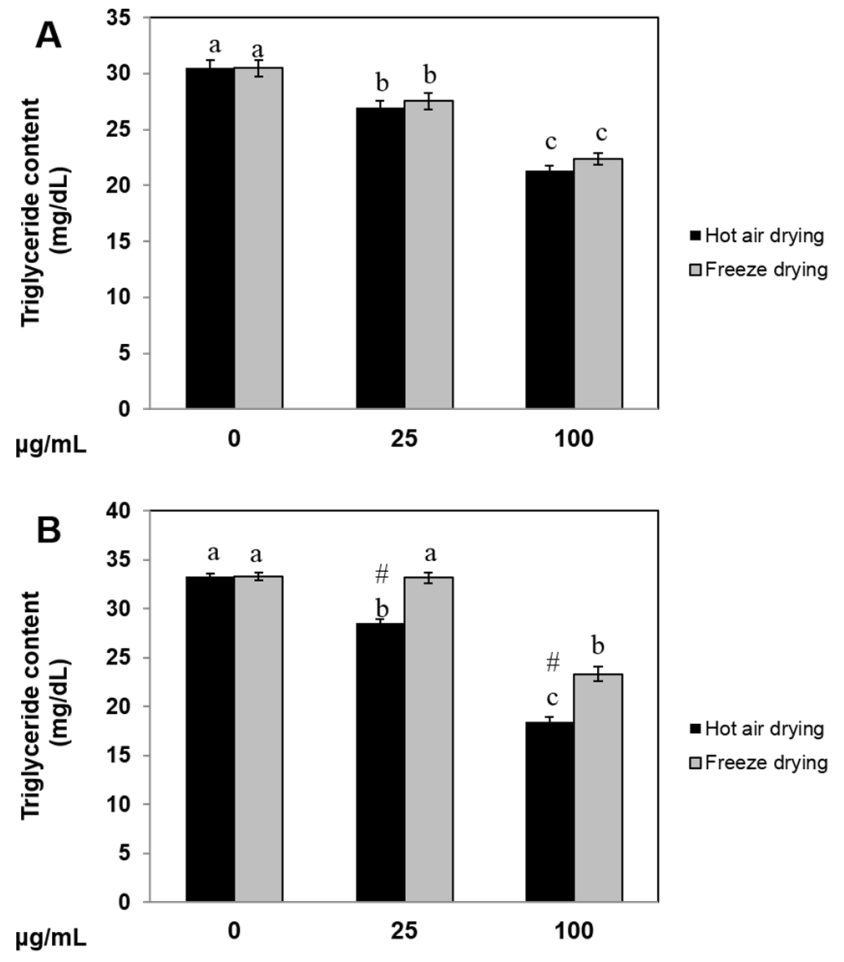

Figure 4. Hot air-dried ramie leaf (HR) or freeze-dried ramie leaf (FR) extracts decreased triglyceride accumulation in 3T3-L1 cells (A) and pig preadipocytes (B). Reported values are means \pm standard error. ${ }^{\mathrm{a}-\mathrm{c}}$ Values with different superscripts are significantly different at $\mathrm{p}<0.05$ according to Tukey's test. \# Significantly difference compared with freeze drying at $\mathrm{p}<0.05$ according to Student's $t$-test. Each experiment was repeated at least triple.

extract treatment showed more sensitive than FR extract treatment on inhibition of LPL activity at $25 \mu \mathrm{g} / \mathrm{mL}$ concentration. These findings imply that HR and FR extract inhibited LPL activity in both 3T3-L1 cells and pig preadipocytes.

\section{DISCUSSION}

Obesity is caused by the growth and expansion of adipose tissue (de Ferranti and Mozaffarian, 2008). Adipocyte differentiation and fat accumulation are closely linked to obesity (Fève, 2005). In the present study, we evaluated the effect of HR or FR extract treatment on the proliferation and differentiation of 3T3-L1 cells and pig preadipocytes at concentrations of 25 and $100 \mu \mathrm{g} / \mathrm{mL}$. The 3T3-L1 cell line and primary preadipocytes are useful models for studying the differentiation of preadipocytes into adipocytes (Kim and Moustaid-Moussa, 2000; Fève, 2005).

Hot-air and freeze drying are common methods for preserving food and feed (Ratti, 2001). Food preparation methods can affect the nutritional and functional qualities of the food. We have investigated to compare the physicochemical composition and antioxidative properties between HR and FR (Kim et al., 2014a, b). There were no significant differences in moisture, crude protein, crude fat, crude ash, and carbohydrate content depending on the drying methods, but the dietary fiber content was significantly higher in FR than in HR. In addition, the contents of vitamin A, E, and C, total minerals, total organic acids and total free sugars in HR were significantly higher than those in the FR. Phenolic compounds such as flavonoids and chlorogenic acid are considered to be the major contributors to the antioxidant ability of plants (Ong et al., 2013). Total polyphenolics, flavonoids, and chlorogenic acid contents in HR and FR used in this experiment were found to be $132.50 \pm 2.76$ and $138.00 \pm 2.64$ tannic acid equivalent $\mathrm{mg} / \mathrm{g}$ dry matter (DM), $119.00 \pm 1.15$ and $124.25 \pm 0.58$ rutin equivalent $\mathrm{mg} / \mathrm{g} \mathrm{DM}$, and $15.24 \pm 0.65$ and $15.78 \pm 0.53 \mathrm{mg} / \mathrm{g}$, respectively. Several studies have shown that the antioxidant capacities of natural products depend on the drying method used (Kim et al., 2007; Ferreira and Luthria, 2010; Gümüşay et al., 2015). Our previous study revealed that both HR and FR extracts had a high 2,2-diphenyl-1-picrylhydrazyl radical scavenging activity and high total flavonoid contents (Kim et al., 2014b), but that there was no difference between them (Chen et al., 1997). Oxidative stress is caused by an imbalance between pro-oxidants and antioxidants and it plays a critical role in the pathology of various diseases (Furukawa et al., 2004). Low levels of oxidative stress allow cells to maintain a normal redox status, but high levels damage cell composition and function ( $\mathrm{Yu}, 1994)$. 

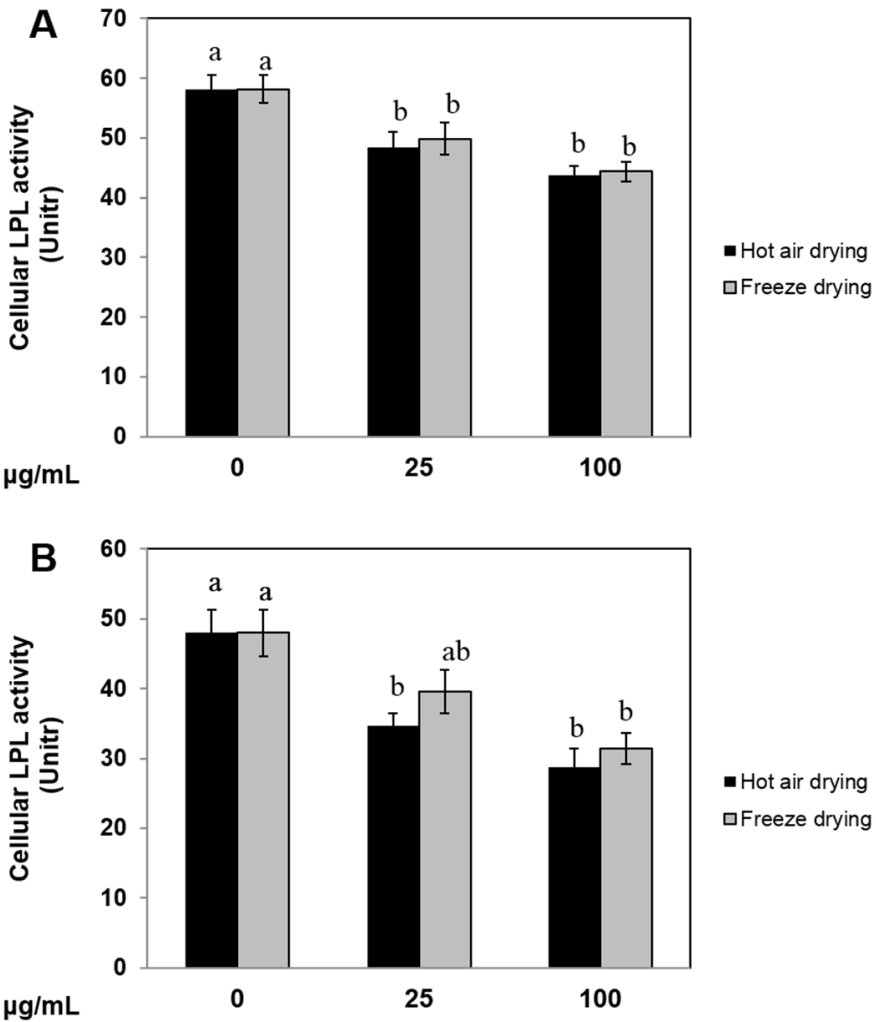

Figure 5. Effects of hot air-dried ramie leaf (HR) or freeze-dried ramie leaf (FR) extracts on lipoprotein lipase (LPL) activity in 3T3-L1 cells (A) and pig preadipocytes (B). Reported values are means \pm standard error. ${ }^{\mathrm{a}-\mathrm{b}}$ Values with different superscripts are significantly different at $\mathrm{p}<0.05$ according to Tukey's test. Each experiment was repeated at least triple.

Obesity increases oxidative stress and induces lipid peroxidation (Vincent and Taylor, 2006). Excessive levels of lipid in the blood can induce elevated oxidative levels in vivo and in vitro (Furukawa et al., 2004; Vincent and Taylor, 2006). In this study, we observed that HR and FR extract treatment inhibits the proliferation and differentiation of 3T3-L1 cells and pig preadipocytes in a dose-dependent manner (Figure 1 and 2). Furukawa et al. (2004) demonstrated that reactive oxidative species was produced during differentiation of 3T3-L1 cells into adipocytes (Furukawa et al., 2004). Therefore, inhibition of proliferation and differentiation by $\mathrm{HR}$ and FR extracts which contain high levels of antioxidants may have the potential to prevent obesity.

In this study, HR and FR extract treatment decreased lipid accumulation in 3T3-L1 cells and pig preadipocytes (Figure 4A, 4B). A dose of $100 \mu \mathrm{g} / \mathrm{mL}$ HR extract significantly inhibited triglyceride accumulation in pig preadipocytes. It inhibited the proliferation and differentiation of 3T3-L1 cells in a similar manner. These results indicated that $\mathrm{HR}$ and FR extract-mediated decrease of proliferation and differentiation might affect the accumulation of lipid in 3T3-L1 cells and pig preadipocytes. Further studies are needed to assess the underlying mechanism. To our knowledge, this study is the first to demonstrate that after $\mathrm{HR}$ and FR extract reduce differentiation of and lipid accumulation in 3T3-L1 cells and pig preadipocytes.

LPL has an important role in lipoprotein metabolism, the hydrolysis of triacylglycerols into free fatty acids, and the formation of monoglyderides from plasma lipoproteins (Wang and Eckel, 2009). LPL acts as a gatekeeper enzyme that determines the amount of free fatty acid that enters cells. Semenkovich et al. (1989) reported that differentiated 3T3-L1 cells had increased levels of the LPL gene and enzyme activity. The results of the present study revealed that HR and FR extract treatment decreases the expression of LPL in 3T3-L1 cells and pig preadipocytes (Figure 5A, $5 \mathrm{~B})$. These indicate that the inhibition of LPL activity following HR and FR extract treatment was, at least in part, caused by the inhibition of differentiation of both cells. Interestingly, at a low dose of HR extract $(25 \mu \mathrm{g} / \mathrm{mL})$, the LPL activity at the cellular level decreased compared to FR treatment, suggesting that HR may have an inhibitory effect on LPL activity in pig preadipocytes.

\section{CONCLUSION}

In summary, treatment with HR and FR extract inhibits the proliferation and differentiation of, lipid accumulation, 
and LPL activity in 3T3-L1 cells and pig preadipocytes. Therefore, we suggest that extracts of natural products such as HR and FR extract may have potential to reduce obesity. Further studies are needed to clarify and compare the mechanism of these two extracts in adipocytes.

\section{CONFLICT OF INTEREST}

We certify that there is no conflict of interest with any financial organization regarding the material discussed in the manuscript.

\section{REFERENCES}

Boeing, H., A. Bechthold, A. Bub, S. Ellinger, D. Haller, A. Kroke, E. Leschik-Bonnet, M. J. Müller, H. Oberritter, M. Schulze, P. Stehle, and B. Watzl. 2012. Critical review: Vegetables and fruit in the prevention of chronic diseases. Eur. J. Nutr. 51:637663.

Cao, Y. 2007. Angiogenesis modulates adipogenesis and obesity. J. Clin. Invest. 117:2362-2368.

Chen, C., A. E. Brodie, and C. Y. Hu. 1997. CCAAT/enhancerbinding protein beta is not affected by tetrachlorodibenzo-pdioxin (TCDD) inhibition of 3T3-L1 preadipocyte differentiation. Obes. Res. 5:146-152.

De Ferranti, S. and D. Mozaffarian. 2008. The perfect storm: obesity, adipocyte dysfunction, and metabolic consequences. Clin. Chem. 54:945-955.

Fernyhough, M. E., E. Okine, G. Hausman, J. L. Vierck, and M. V. Dodson. 2007. PPARgamma and GLUT-4 expression as developmental regulators/markers for preadipocyte differentiation into an adipocyte. Domest. Anim. Endocrinol. 33:367-378.

Ferreira, J. F. S. and D. L. Luthria. 2010. Drying affects artemisinin, dihydroartemisinic acid, artemisinic acid, and the antioxidant capacity of Artemisia annua L. leaves. J. Agric. Food Chem. 58:1691-1698.

Fève, B. 2005. Adipogenesis: cellular and molecular aspects. Best Pract. Res. Clin. Endocrinol. Metab. 19:483-499.

Furukawa, S., T. Fujita, M. Shimabukuro, M. Iwaki, Y. Yamada, Y. Nakajima, O. Nakayama, M. Makishima, M. Matsuda, and I. Shimomura. 2004. Increased oxidative stress in obesity and its impact on metabolic syndrome. J. Clin. Invest. 114:1752-1761.

Green, H. and O. Kehinde. 1975. An established preadipose cell line and its differentiation in culture. II. Factors affecting the adipose conversion. Cell 5:19-27.

González-Castejón, M. and A. Rodriguez-Casado. 2011. Dietary phytochemicals and their potential effects on obesity: A review. Pharmacol. Res. 64:438-455.

Gümüşay, Ö. A., A. A. Borazan, N. Ercal, and O, Demirkol. 2015. Drying effects on the antioxidant properties of tomatoes and ginger. Food Chem. 173:156-162.

Houpt, K. A., T. R. Houpt, and W. G. Pond. 1979. The pig as a model for the study of obesity and of control of food intake: A review. Yale J. Biol. Med. 52:307-329.
Kim, A. R., H. J. Lee., H. O. Jung, and J. J. Lee. 2014a. Physicochemical composition of ramie leaf according to drying methods. Prev. Nutr. Food Sci. 43:118-127.

Kim, A. R., S. T. Kang, E. Jeong, and J. J. Lee. 2014b. Effects of ramie leaf according to drying methods on antioxidant activity and growth inhibitory effects of cancer cells. Prev. Nutr. Food Sci. 43:682-689.

Kim, S. and N. Moustaid-Moussa. 2000. Secretory, endocrine and autocrine/paracrine function of the adipocyte. J. Nutr. 130:3110S-3115S

Kim, S. H., H. S. Choi, M. S. Lee, and M. S. Chung. 2007. Volatile compounds and antioxidant activities of Adenophore remotiflora. Korean J. Food Sci. Technol. 39:109-113.

Lee, Y. R., J. W. Noh, I. G. Hwang, W. J. Kim, Y. J. Lee, and H. S. Jeong. 2009. Chemical composition and antioxidant activity of ramie leaf (Boehmeria nivea L.). Food Sci. Biotechnol. 18:1096-1099.

Litten-Brown, J. C., A. M. Corson, and L. Clarke. 2010. Porcine models for the metabolic syndrome, digestive and bone disorders: A general overview. Animal 4:899-920.

Nilsson-Ehle, P. and M. C. Schotz. 1976. A stable, radioactive substrate emulsion for assay of lipoprotein lipase. J. Lipid Res. 17:536-541.

Ong, K. W., A. Hsu, and B. K. H. Tan. 2013. Anti-diabetic and anti-lipidemic effects of chlorogenic acid are mediated by AMPK activation. Biochem. Pharmacol. 85:1341-1351.

Ratti, C. 2001. Hot air and freeze-drying of high-value foods: A review. J. Food Eng. 49:311-319.

Semenkovich, C. F., M. Wims, L. Noe, J. Etienne, and L. Chan. 1989. Insulin regulation of lipoprotein lipase activity in 3T3L1 adipocytes is mediated at posttranscriptional and posttranslational levels. J. Biol. Chem. 264:9030-9038.

Spurlock, M. E. and N. K. Gabler. 2008. The development of porcine models of obesity and the metabolic syndrome. J. Nutr. 138:397-402.

Suryawan, A., L. V. Swanson, and C. Y. Hu. 1997. Insulin and hydrocortisone, but not triiodothyronine, are required for the differentiation of pig preadipocytes in primary culture. J. Anim. Sci. 75:105-111.

Vincent, H. K. and A. G. Taylor. 2006. Biomarkers and potential mechanisms of obesity-induced oxidant stress in humans. Int. J. Obes. 30:400-418.

Wang, H. and R. H. Eckel. 2009. Lipoprotein lipase: from gene to obesity. Am. J. Physiol. Endocrinol. Metab. 297:E271-E288.

Wei, J., L. Lin, X. Su, S. Qin, Q. Xu, Z. Tang, Y. Deng, Y. Zhou, and S. He. 2014. Anti-hepatitis B virus activity of Boehmeria nivea leaf extracts in human HepG2.2.15 cells. Biomed. Rep. 2:147-151.

Wise, L. S. and H. Green. 1979. Participation of one isozyme of cytosolic glycerophosphate dehydrogenase in adipose conversion of 3T3 cell. J. Biol. Chem. 254:273-275.

Xu, Q. M., Y. L. Liu, X. R. Li, X. Li, and S. L. Yang. 2011. Three new fatty acids from the roots of Boehmeria nivea (L.) Gaudich and their antifungal activities. Nat. Prod. Res. 25:640647

Yu, B. P. 1994. Cellular defenses against damage from reactive oxygen species. Physiol. Rev. 74:139-162.

Yun, J. W. 2010. Possible anti-obesity therapeutics from nature--A review. Phytochemistry 71:1625-1641. 